\title{
SOBRE A OCORRÊNCIA DE VERTEBRADOS FÓSSEIS TRIÁSSICOS NA REGIĀO DE SANTANA DA BOA VISTA (RS)
}

\author{
Ubiratan Ferrucio Faccini (NESE/UNISINOS) \\ Cesar Leandro Schultz (CIGO/UFRGS) \\ Cláudio Eduardo Figueiredo (UNISINOS - Curso de Geologia) \\ Lucena Rosa Sangineto (UNISINOS - Curso de Geologia) \\ Soraia Cavagnolli Soares (UNISINOS - Curso de Geologia)
}

Com exceção dos depósitos do grupo Camaquã, todas as de mais coberturas sedimentares do Escudo Sul-riograndense tem sidotra dicionalmente referidas pela denominação genérica de Formação Cane leiras, com idade originalmente atribuída ao Devoniano. Contudo, ma peamentos mais recentes passaram a considerar esta unidade como cro nocorrelata aos depósitos gondwânicos do Grupo Rosário do Sul, embo ra com base em registros fossiliferos esparsos e inconclusivos. Nes te trabalho apresentamos a caracterização preliminar dos achados de vertebrados fósseis, pertencentes à Formação Caneleiras, na região de Santana da Boa Vista (RS) e a associação faciolögica dos depósí tos que os contém.

Dentre os diversos materiais coletados, às margens do Ar roio Vargas, no Passo da Campina, várias peças podem ser seguramen te caracterizadas como pertencentes ao grupo dos rincossauros, alēm de um ramo mandibular de um cinodonte gonfodonte. Estes exemplares são provenientes de um pacote de pelitos vermelhos, maciços ou tenue mente laminados, contendo veios e concreções carbonáticas. Estes pe litos fossilíferos, por sua vez, recobrem fácies de arenitos bran cos, de origem fluvial "braided", ricos em quartzo, que se assentam erosivamente sobre lobos sigmoidais, constituídos por arenitos mui to finos e silticos, de cor vermelha, relacionados à depösitos de frentes deltaícas lacustres de pequenas proporções.

Estes achados fōsseis ganham significação estratigráfica na medida em que os rincossauros foram um grupo de répteis diāpsi dos, herbívoros de médio porte, cujos restos fósseis já foram regis trados em todos os continentes, à exceção de Austrália e Antártida, exclusivamente em sedimentitos de idade triássica.

No Rio Grande do Sul, os rincossauros ocorrem principal mente no topo da Formação Santa Maria (Fauna Local de Alemoa, andar Carniano), onde constituem mais de $90 \%$ do total da fauna, embora se jam registradas, subordinadamente, formas primitivas do grupo também 
na base desta unidade (Fauna Local de Pinheiros, andar Ladiniano), porção amplamente dominada por dicinodontes, atē agora não encontra dos em Santana da Boa Vista. Com relação aos cinodontes, muito embo ra tenham surgido no Permiano, também não há, no Rio Grande do sul, qualquer registro de sua ocorrência fora dos estratos triássicos da Formação Santa Maria.

Portanto, os pelitos vermelhos que ocorrem em Santana da Boa Vista, por suas características litológicas, fácies associadas e principalmente por seu conteúdo fossilífero, de idade inequivoca damente triássica, representam uma porção preservada da Formação San ta Maria sobre o Escudo Sul-riograndense, portadora de exemplares pertencentes à Fauna Local de Alemoa, com idade situada no andar Car niano.

A identificação da Formação Santa Maria na região, corres pondendo ao topo de uma associação constituỉda, em direção à base, por arenitos fluviais, correlacionáveis ao Membro Passo das Tropas e lobos sigmoidais, fácies característica da Formação Rio do Rasto, coincidem com a normalidade do empilhamento estratigráfico observa do em toda faixa de afloramento destas unidades gondwânicas no Esta do. Isto significa que, uma vez individualizadas tais unidades, com características faciológicas, posicionamentos estratigräfico e deno minações formais reconhecidas e consagradas, o termo "Caneleiras" torna-se inadequado e impróprio, devendo ser abandonado, ao menos para a região de Santana da Boa Vista. 